\title{
Education Planning and Its Implications for Education Policy during the Covid-19 Pandemic
}

\author{
Feiby Ismail ${ }^{1, a^{*}}$, Abdul Muis Daeng Pawero ${ }^{1, b} \&$ Mardan Umar ${ }^{2, c}$ \\ ${ }^{1}$ Faculty of Tarbiyah \& Teachers Training, IAIN Manado, Indonesia. \\ ${ }^{2}$ State University of Manado, Minahasa, Indonesia. \\ a feibyismail@iain-manado.ac.id; babdul.pawero@iain-manado.ac.id; c mardanumar@unima.ac.id \\ *Corresponding Author : feibyismail@iain-manado.ac.id
}

\begin{abstract}
Indonesian education during the Covid-19 era entered a different situation. The real situation has long been predicted by technology experts that all areas of life will enter the realm of digital technology-based activities, including education. For this reason, education in Indonesia must be able to find new directions for education in formulating policies to be taken. One of the important things that must be prepared is at the education planning level. The problem that needs to be studied is how educational institutions formulate educational program planning during the Covid-19 pandemic while maintaining the quality of education. Educational planning carried out by educational institutions must reflect the existence of a vision, mission, goals and work plans, as raw materials or a reference for educational policies at the managerial level. This paper will discuss the education planning process in terms of its implications for quality-oriented education policy during a pandemic.
\end{abstract}

Keywords: educational planning; covid-19 pandemic; education policy; quality

\section{Introduction}

The demands of the use of technology in learning during the Covid-19 pandemic cannot be met with readiness by the government. The proof is, not all educational institutions are ready to face the demands of technology-based online learning. Problems regarding the quality of human resources, (low mastery of technology by educators or teachers and administrative staff), the ability of students (unequal ability to use technology, unequal economy in providing technology-based learning tools such as gadgets, laptops and android cellphones), as well as internet network facilities that have not been spread in various places. Education during the Covid-19 pandemic requires readiness from various aspects, especially the readiness of teachers and students in undergoing online learning. In addition, the availability of internet facilities and networks is an obligation for digital communities who live and interact through technology services.Deming and Philip B. Crosby, as quoted by Nasution (2004:7; Sallis:2012) states that quality is conformity with market needs or quality is whatever the consumer needs and wants. As stated by Umar and Ismail (2017), the quality of education must remain a priority in learning.

The 21st century is a century of rapid industrial development supported by advances in science and technology. This progress and development requires that people are able to take advantage of various technological applications, so that they can change the way they think, act and even change the form and pattern of human life that is completely different from previous lives. In such a society, the role of educational institutions is very much needed in providing encouragement, guidance and facilities for students to acquire knowledge and skills in using technology. The rapid industrial progress in an open world has given birth to a new culture, namely a culture of materialism and commercialism, which has triggered the birth of a new, highly consumeristic lifestyle. A world that is flat and controlled by free markets makes competition an obligation and is even a necessity in triggering higher quality and affordable production products for the people at large. With this global reality, educational institutions are increasingly being challenged to take part. Not only fortifying themselves and maintaining the possibility of domination by other nations, but also becoming an actor in the arena of global competition with other nations. In an effort to build the foundation of educational institutions in moving towards global competence, the optimization of educational planning is something that is necessary in developing education at the school level, as well as a source of policy reference at the national education policy level. 
Educational planning in facing this global challenge means selecting or determining programs/ strategies/steps taken to realize the educational goals set to face challenges in the future. Educational planning that is carried out is basically a form of responsibility from various alternative choices that exist in life. The essence of educational planning can also mean a process of making a map/route of travel towards the desired future of education. As a process, educational planning will continue without stopping, it will continue to develop, update, and adapt along the journey (Machali,I\& Kurniadin, D.,2016:145). Thus, educational planning to face global challenges is an effort to maximize the consequences of the choicedecisions made regarding current education policies for the future and as an effort to anticipate the existence of education policies that are not right on target.

In accordance with observations in Indonesian educational institutions, there are still difficulties in the ability of teachers to utilize information technology in learning during the Covid-19 pandemic. Therefore, this paper examines the focus of educational planning on quality aspects amid the Covid-19 pandemic. It is hoped that this paper can provide input for education policy making in Indonesia.

\section{Methods}

This research is a library research that focuses on educational planning problems and their implications for education policy in Indonesia during the Covid-19 pandemic.Sources of library data reviewed are based on reference books and journal articles that are processed and compared with existing education policies in Indonesia. Data in the form of theory and previous research studies were taken into consideration in examining more deeply the problem of educational planning in the midst of the Covid-19 pandemic. The analysis technique used is content analysis by paying attention to the linkage of the problem being studied with the situation and conditions of education in Indonesia.The validity of the findings is determined by several examination techniques. The implementation of the inspection technique is based on a number of criterianamely credibility, transferability, reliability, and certainty.

\section{Results And Discussions}

As a form of education planning formulation in facing Global competence as described above, there are three major indicators that the authors can put forward in supporting the education planning, namely teacher competence, optimization of the quality of educational institutions, and the maximum implementation of National Education Standards.

1. Teacher competence to face the challenges of the 21 st century.

The $21^{\text {st }}$ century marked by the flow of informastization and industrialization has changed the way of life of humans as individuals, as communities, and as citizens of the nation. Changes in lifestyle, the use of gadgets, smartphones, digital applications, and so on have caused the industrialization and informatization processes to penetrate all corners of human life. Starting from primary to secondary needs, starting from the workplace to in the room, shows that no human can escape from the flow of industrialization and informatization of the 21st century. Facing this challenge, teachers are faced with two choices. First, just being surrendered or just nrimo to the situation and carrying out activities accordingly, or secondly, becoming an actor who plays a role as a player in the informatization and industrialization process.

As educators who act as actors in creating a competent and character generation of the nation, like it or not, the teacher must choose the second option, which is to become an actor who plays a role as a player in the informatization and industrialization process. Along with the characteristics of the 21st century as described above, teachers are challenged to continue to improve their professionalism as teachers and educators. In addition to professionalism, teachers are also challenged to face several keys to the success of the world of education, namely, competition, character, integrity and high quality. Some of the challenges of the 21st century that must be addressed by teachers can be described as follows; The development of science and technology is so fast and fundamental. With this condition the teacher must be able to adapt responsively, wisely and wisely. Responsive means that teachers must be able to master science and technology products well, especially those related to education. Without good science and technology knowledge, teachers will be left behind and even become victims of science and technology, which in the end only makes teachers "surrender" to the situation.

The moral crisis that hit Indonesia. As a result of the influence of the development of technology applications, there has been a shift in the values that exist in people's lives, especially the younger generation and students. Through education, teachers are challenged to continue to improve creativity using technology in instilling students' ability to innovate while instilling moral values. Social crises such as crime, violence, unemployment and poverty that occur in society. As a result of industrial development and capitalism, social problems arise in society. Those who are weak in terms of education, access and economy are most 
vulnerable to becoming victims. It is a challenge for teachers to respond to this reality through the world of education. This is because schools are educational institutions that have won the trust of the community, so they must be able to produce students who are ready to live in any situation and condition.

Identity crisis in part of Indonesian society. The process of informatization and industrialization in the 21st century has also irradiated the identity and culture of the Indonesian nation so that it has influenced the national spirit and nationalism of the younger generation. For this reason, teachers as guardians of the values and character of the young generation including the spirit of nationalism, must be able to provide awareness to the younger generation of the importance of the spirit of nationalism in the life of the nation and state (Oviyanti, 2013: 264-282). Institutions are continuously mobilized to improve the quality of their educational institutions (Ismail, F. \& Umar, M., 2020: 78-95) In an effort to create quality educational institutions, there needs to be a cooperation agreement between teachers, parents, administrators and students that schools must be places that maximize learning for students, where students feel happy in the learning process. A happy learning environment, of course, will result in academic success (Danielsen, $\mathrm{O}$ Samdal, Hetland, and Wold,2010: 303-320). Academic success is the achievement of educational institutions in helping to realize the goals of national education. Therefore, the learning atmosphere can also direct students as a direction for them to be able to grow up according to their true potential and self-concept, so that they can grow, compete and maintain their lives in the informatization and industrialization era of the 21st century.Based on the explanation above, it can be seen that in the informatization and industrialization era of the 21st century, teachers are not just teaching, but must become "managers" in managing the learning process. The point is, each teacher is expected to be able to create learning conditions that stimulate learning creativity, motivation, and multimedia abilities of students in order to achieve the expected learning objectives. In addition, in an effort to increase professionalism, teachers should have adequate capacity in carrying out the task of fostering, guiding, and directing students in fostering a spirit of excellence, learning motivation, personality and noble character which is in line with the Indonesian culture. Thus, a professional teacher is a determining factor for the quality education process in facing the challenges of education during the Covid-19 pandemic.

\section{Optimizing the Quality of Educational Institutions.}

Improving the quality and competitiveness of Indonesia's human resources as a result of education has become a national commitment. The 2015-2019 National Mid-Term Development Plan mentions one core substance of the action program in the education sector, namely rearranging the school curriculum so that it can encourage the creation of student outcomes that are able to answer human resource needs to support national and regional growth, as well as prepare skilled personnel to compete in global scale especially facing the ASEAN Economic Community (Kementerian Perencanaan Pembangunan Nasional: 34-41). Thus, improving the quality of educational institutions as a whole is very important and urgent to do to achieve this goal. Quality of education is an important issue that has never been lost in education management. This is because quality educational institutions are the main concern of every educational institution. All efforts of educational.

To function education proportionally and to optimize the quality of educational institutions, improvements must be made at all strategic levels such as the level of education policy, the level of education managers, and teachersin the level of education implementers (Pawero,2017: 166-178). However, what deserves serious attention is the handling of problems at the level of education implementers, because no matter how good the curriculum is, or however adequate the educational facilities are, if the teacher is not able to play its role properly, educational activities will not develop as expected. The success or failure of educational activities at this level will determine the success or failure of educational activities as a whole at all strategic levels (Mulyasana, 2015:5). For this reason, the function of education planning, besides being directed at transforming positive values, is also developed as a tool to empower all potential students so that they can grow in line with the demands of religious, social, economic and political needs in facing the challenges of informatization and industrialization.

On the political side, the formulation of education policies from the government must also be oriented towards the development of skills and creativity of students, the community and the young generation. This is because education is the most fundamental means of advancing the nation and society. As a political policy holder, the government has a big role in developing and improving the quality of education. Political upheaval, meaning that the fluctuating political climate in a country will affect the condition of education in that country(Hoddin, 2020: 15-30). Quality education will certainly not be achieved without an educational program that prepares its citizens or actors with the values to be realized. 
3. Maximum Implementation of National Education Standards.

Education as stated in Law Number 20 of 2003 concerning the National Education System is a conscious and planned effort to create an atmosphere of learning and a learning process so that students actively develop their potential to have religious spiritual strength, self-control, personality, intelligence. , noble character, and skills needed by him, society, nation and state.

The educational paradigm is then formulated into the functions and goals of national education. Law Number 20 of 2003 concerning the National Education System stipulates that national education has the function of developing capabilities and shaping the character and civilization of the nation with dignity in the context of developing the intellectual life of the nation; aims to develop the potential of students in order to become human beings who believe and fear God Almighty, have noble character, are healthy, knowledgeable, capable, creative, independent, and become democratic and responsible citizens.

From the explanation above, it is clear how important the position of education is in the midst of rampant informatization and industrialization. Global life in an open world with free trade and regional cooperation requires quality human beings. Quality humans are humans who can compete in a good way. In competition, individual quality is needed so that the results of the work or products produced can compete, which means pushing towards quality that is increasingly increasing. Good quality which continues to increase can only be created by humans who have the ability to compete. The ability to compete can only be produced by education that is conducive to the birth of competitive individuals (Tilaar, 2010:15). The success of educational institutions in creating competitive students can be achieved when all personnel involved in educational institutions continue to strive to implement the National Education Standards in their educational institutions (Pawero, 2018:42-59).

One of the points contained in the National Education Standards is the education process standard. This is related to the implementation of learning including the atmosphere and learning environment during the learning process. The preparation of educational process standards is needed to determine the learning activities carried out by teachers as an effort to achieve graduate competency standards (Sanjaya, 2019:49). Thus, educational process standards can be used as guidelines by every teacher in managing the learning process and determining components that can affect the performance of educational institutions.

The Education Process Standard is one of the 8 (eight) national education standards as stipulated in Article 35 Paragraph (1) of Law number 20 of 2003 concerning the National Education System and Law number 19 of 2005 concerning National Education Standards. determine the minimum quality of the learning process that must be carried out by the teacher in each education unit. So that learning in the classroom can be of higher quality, each teacher can develop a further learning process according to their conditions and needs. Therefore, a quality learning process has a very important role for character building and empowering the potential of students in each educational unit. This is very reasonable, because most students will spend their life in the world of schooling for 12 years.

The educational process during that time is very important for students as a momentum to develop and empower their potential effectively with the opportunities and challenges they find, both now as young people and in the future as adults. Therefore, the preparation of students from an early age in various ways is very reasonable. Educational process standards can be used as a reference in new directions of educational planning.

Related to the new direction of education planning, it is necessary to make strategic efforts as a first step in the process of delivering education. Ki Hajar Dewantara, as quoted by Dedy Mulyasana, sees the importance of implementing a humanistic approach in the educational process. Therefore, he views the importance of applying the following five educational principles;

a. Principle of Independence. The process of implementing education is carried out with due regard to the independence of students. They are given independence but still pay attention to the prevailing ethics, rules and values. The principle of independence does not mean value-free education but freedom that is developed with ethics, rules and values.

b. Principles of Nature. The educational process is carried out in accordance with the nature of nature. This means that the educational process is managed by paying attention to the nature and nature of children as humans. Every child has a variety of different talents, attitudes, abilities, interests and needs. Education is developed in line with this nature and diversity.

c. Cultural Access. A good educational process is an educational process carried out by taking a cultural approach and being developed in line with the demands of civilization and the future challenges of the nation.

d. Nationality Principle. Education is carried out by paying attention to the principle of nationality. This means that the management and development of education in Indonesia is carried out by taking into account the interests and national identity.

e. Principles of Humanity. Education is carried out by paying attention to human values. This is in line 
with the nature of education as a humanizing process that is carried out humanely. That is, education is not meant to turn students into machines and robots, but to develop children's potential and abilities in line with the nature of themselves as humans (Mulyasana, 2015:37).

Based on the above view, it can be understood that learning which is considered good in the era of informatization and industrialization in the 21st century is a learning pattern that is organized in a democratic manner. Among other things, democratic learning has meaning:

a. Learning patterns that prioritize the learning needs of the participants. This means that the learning process pays more attention to and prioritizes the learning needs of students rather than merely administrative needs;

b. The growth of autocritical learning dynamics. This means that educators (teachers) are ready to criticize students and are also ready to be criticized by students. The goal is to improve the quality of the process and learning outcomes';

c. Education is implemented fairly, meaning that educators treat students fairly. It is necessary for educators to be able to free themselves from the interests of their ego and / or group;

d. Implementers of education must be able to implement the principles of equitable learning, namely the principles of learning that function something in its place according to its role and use. In the principle of fair learning, all students are treated equally according to their status as learning citizens who have the same rights and obligations;

e. Educators do not treat students in a discriminatory manner, namely differentiating their status and rights from one another;

f. The learning process is carried out by paying attention to and upholding human rights. Students have the right to have their opinions heard, respect for their dignity, protect their status, and develop all their potential and identity according to their abilities, interests, motivations, needs and learning styles. Educators are not entitled to treat students beyond the limits of the rights and dignity of students. That is, it is not allowed to insult and be rude to students in public, let alone make threats and violence against students;

g. A democratic learning pattern does not mean a value-free learning pattern, meaning that the learning process is still bound by ethics, values, and rules that apply especially religious values.

Based on the explanation of educational planning and its implications for education policy, especially in the era of informatization and globalization as described above, it can be understood that education is not only understood as "school children who go to school" alone.Therefore, the new direction of education planning must be able to produce policy outputs that can accommodate the following elements;

First, Educational planning must formulate education broadly, not just being limited as schooling. If education is interpreted as merely schooling, it will appear that the responsibility for education is all devolved to the responsibility of the school. This of course causes education to be alienated from real life and throws people away from their educational responsibilities. The formulation regarding the existence of types of formal and non-formal education needs to be refined again, namely complementing it with in-formal education, where informal education is precisely what plays an important role in shaping human behavior. In facing the era of industrialization and informatization, education policies must include these elements of in-formal education.

Second, Facing the challenges of informatization and industrialization in the 21st century, the formulation of education policies should involve the community as much as possible. This is because education in reality cannot be separated from the whole life of society, or in other words it is part of culture. Thus, the aim of education which has been aimed solely at the formation of intellectuals must be changed to include the formation of the entire spectrum of human intelligence. Therefore, the process of education and learning in schools is not only aimed at a small group of children who have academic intelligence, but must also include the development of various kinds of intelligence such as emotional intelligence, aesthetic intelligence, interpersonal intelligence, and so on.

Based on the overall discussion as above, the direction of educational planning must lead to educational policies that direct humans not only to be intelligent in the sense of mastering academic intelligence but the most important thing is to make students able to master science and technology skills as well as to become cultured human beings. Thus, education planning in facing the informatization and industrialization era of the 21st century must realize a policy formulation that makes education as educated human being as well as educated and civilized human being, namely education that is capable of turning people into intelligent and civilized human beings. 


\section{Conclusion}

Based on the discussion as discussed above, several important points can be drawn as follows;

First, Educational planning is an effort to realize the formulation of educational policies in building social forces that contribute to shape, style and direction in the life of Indonesian society in the future. Educational planning in an effort to face the challenges of informatization and industrialization in the 21st century is an effort to determine programs/strategies/steps taken to realize the stated educational goals. So educational planning must be the main foundation of Indonesia's education building

Second, As a form of education planning formulation in facing global competence, there are three major indicators that the authors can put forward in supporting educational planning, namely teacher professionalism and competence, optimizing the quality of educational institutions, and maximally implementing National Education Standards.

Third, Educational planning must produce educational policy formulations that support the formation of the entire spectrum of learners' intelligence. Therefore, the education/learning process in schools is not only aimed at a small group of children who have academic intelligence, but must also include the development of various kinds of intelligence such as emotional intelligence, aesthetic intelligence, interpersonal intelligence, and so on.

\section{References}

Danielsen, O. Samdal, Hetland, and Wold. (2010). "School-related social support and students'perceived life satisfaction." The Journal of Educational Research, vol. 102, No. 4, 303-320, DOI: 10.3200/JOER.102.4.303320.

Ismail, F., dan Umar. M., (2020). "Implementasi Penjaminan Mutu di Lembaga Pendidikan Islam;Studi Multisitus di MAN Model 1 Manado, MAN 1 Kotamobagu dan MAN 1 Kota Bitung." Jurnal Ilmiah Iqra' Vol. 14, No. 1, h. 78-95.

Kementerian Perencanaan Pembangunan Nasional, Rancangan Awal; Rencana Pembangunan Jangka Menegah Nasional, BAB II, h. 34-41.

Machali, I., dan Kurniadin, D., (2016). Manajemen Pendidikan; Konsep dan Prinsip Pengelolaan Pendidikan, Yogyakarta: Ar-Ruzz Media.

Pawero, AbdulMuis Daeng., (2018). "Analisis Kritis Kebijakan Kurikulum Antara KBK, KTSP, dan K-13." Jurnal Ilmiah Iqra' Vol. 14, No. 1, h.42-59.

Pawero, Abdul Muis D., (2017). "Analisis Kritis Kebijakan Standar Kompetisi Lulusan dan Standar Isi Kurikulum Pendidikan Islam." JIEP; Journal of Islamic Education Policy, Vol.2, No. 2, h.166-178.

Mulyasana, D.,2015.Pendidikan Bermutu dan Berdaya Saing. Bandung; PT. Remaja Rosdakarya.

Oviyanti, F., (2013). "Tantangan Pendidikan Islam di Era Global." Nadwa; Jurnal Pendidikan Islam, Vol.7, No. 2, h. 264-282.

Sanjaya, W., (2019). Strategi Pembelajaran. Jakarta.

Hoddin, M. Sholeh., (2020). "Dinamika Politik Pendidikan Islam Di Indonesia; Studi Kebijakan Pendidikan Islam Pada Masa Pra-Kemerdekaan Hingga Reformasi." Jurnal Ilmiah Iqra' Vol. 14, No. $1,15-30$.

Tilaar, H.A.R. (2010). Paradigma Baru Pendidikan Nasional. Jakarta; PT. Rineka Cipta.

Umar, M., \& Ismail, F. (2017). Peningkatan Mutu Lembaga Pendidikan Islam. Iqra' Jurnal Pendidikan Islam, 11(2), 1-24.

Undang-undang R.I, Nomor 20 tahun 2003 tentang Sistem Pendidikan Nasional.

Nasution, M.N. (2004), Manajemen Mutu terpadu, Jakarta: Ghalia Indonesia, Cet. ke-3.

Sallis, E., (2012). Total Quality Management in Education (Manajemen Mutu Pendidikan), Cet. XVI, Jakarta : Erlangga. 